\title{
Universal iron fortification of foods: the view of a hematologist
}

José Murilo Martins

Universidade Federal do Ceará - UFC, Fortaleza, CE, Brazil
Conflict-of-interest disclosure:

The authors declare no competing financial interest

Submitted: 11/20/2012

Accepted: 11/26/2012

Corresponding author:

José Murilo Martins

Av. Beira Mar 3660/ap401

60165-121 Fortaleza, CE, Brazil

murilo@espacoaberto.com.br
With the objective of reducing the high incidence of iron deficiency anemia, the Brazilian National Health Surveillance Agency (ANVISA) adopted Resolution 344 in December 2002, which made the addition of iron and folic acid to all industrialized wheat and maize flours in Brazil compulsory. After a series of doubts about this universal measure of food fortification, a review of case reports on long-term medicinal iron intake published in the medical literature was undertaken to investigate the clinical behavior of this hematological conduct. Long-term medicinal iron ingestion is an extremely rare and serious situation. The data suggest that there are cases of hemochromatosis in women whose illnesses were accelerated with this therapy. It is very difficult to determine the amount of iron ingested by Brazilian citizens in the current system of fortification, but there is evidence that there has been an appreciable increase. Although iron fortification of food has been recognized by some authors as a good strategy to combat iron deficiency, some nations have abandoned this measure. The patient with hemochromatosis is the most affected by compulsory iron fortification and as this disease is now considered a public health problem, we believe that Resolution 344 of ANVISA should be reviewed in order to find a solution beneficial to all segments of the Brazilian population; one should not try to correct one condition (iron deficiency) by exacerbating another (acceleration of iron overload cases).

Keywords: Anemia, iron-deficiency; Hemochromatosis; Food,fortified; Case reports

\section{Introduction}

Iron is part of the hemoglobin molecule whose main function is to carry oxygen from the lungs to the tissues. In the body other molecules containing iron, such as myoglobin and some enzymes, also have important functions.

The total amount of iron in the human body is 4.0 grams with 2.5 grams in hemoglobin, 0.5 grams in myoglobin and enzymes and 1.0 gram as a reserve. For men, $0.9 \mathrm{mg}$ of iron is required every day to restore the amount lost due to the shedding of cells from the intestine, skin and urinary tract. For women in the childbearing age, iron requirements are about $1.3 \mathrm{mg}$ per day, due to menstrual losses. In pregnant women this rises even further to $3.0 \mathrm{mg}$ per day. In the period of growth the need for iron is also high. There is no physiological mechanism of excretion of this metal and the shedding of cells in the gastrointestinal tract is the only effective way that the body can eliminate it.

\section{Iron deficiency}

Iron deficiency is the most common hematological disorder involving about $30 \%$ of the world population. This disease most often affects children, women of child-bearing age and pregnant women. Its prevalence varies according to region and socioeconomic conditions. In Brazil this illness has great epidemiological significance.

Chronic blood loss (gastrointestinal, hypermenorrhea, parasitic infections, acetylsalicylic acid, anti-inflammatory agents, Rendu-Osler-Weber Syndrome), gastrectomy, repeated pregnancies, malnutrition and growth are all causes of iron deficiency anemia.

Treatment consists in the oral or parenteral replacement of iron, blood transfusions (when necessary) and iron fortification of foods. It is essential to determine the cause of the anemia.

\section{Diseases related to iron overload}

Much research has been carried out in recent years to better understand these diseases. Cançado and Chiattone ${ }^{(1)}$, in a recent work, presented the main clinical syndromes related to iron overload including: 1 - primary (hereditary hemochromatosis types 1, 2, 3, 4 and other types); 2 - Secondary transfusional diseases (including chronic hemolytic anemias); and 3 Non-transfusion diseases such as chronic liver disease, and African and iatrogenic iron overload.

Hereditary hemochromatosis is the prototype of diseases linked to iron overload; it is an autosomal recessive disease resulting from an abnormality of the hemochromatosis gene (HFE) on chromosome 6, most commonly involving the $\mathrm{C} 282 \mathrm{Y}$ mutation. There is a high prevalence in Northern Europe countries, but it has also been reported in several Brazilian publications ${ }^{(2-4)}$. Other 
chromosomal abnormalities are H63D, S65C and V256I. This disease results from an inappropriate increase in iron absorption by the intestines with the surplus metal being accumulated in the tissues. The disease evolves with liver cirrhosis $(30 \%$ complicated with liver cancer), splenomegaly, severe heart disease, diabetes, dark skin, endocrine disorders and neuropathy.

\section{Resolution 344 of ANVISA, December 13, 2002}

The Brazilian government, concerned about the high incidence of iron deficiency anemia in children and pregnant women in the country, instituted a policy of mass or universal food fortification. Thus, since December 13, 2002, Resolution 344 of ANVISA, requires the addition of at least $4.2 \mathrm{mg}$ of iron and $150 \mathrm{mcg}$ of folic acid to each 100 grams of industrialized wheat and maize flour in Brazil ${ }^{(5)}$. This measure was published on December 18, 2002 with 18 months for companies to comply; this period ended on June 18, 2004.

In a recent work entitled "Considerations on the food fortification with iron and folic acid" published in the Revista Brasileira de Hematologia e Hemoterapia we demonstrated our concern about this measure ${ }^{(6)}$.

Iron and folic acid are two medications used in medicine and, as such, have both beneficial and adverse effects and thus can be harmful to health. The beneficial effects have been widely analyzed in works on the theme, but little has been discussed about the toxicity of these drugs in the healthy population and in patients with iron overload.
As these flours are basic to our diet, it can be concluded that every citizen in the country, regardless of age, gender, ethnic background, occupation, socioeconomic condition, healthy or carrier of some illness, began to ingest iron and folic acid every day, whether needed or not.

Some questions were asked related to: the use of these two important medicines in more than 190 million people, without any medical control; the risk of administering iron to anemic patients without first discarding the hypothesis of anemia secondary to a gastrointestinal neoplasm for example and whether mandatory food fortification with iron does not worsen the health of ordinary people or patients suffering from iron overload illnesses.

\section{Prolonged intake of medicinal iron}

The literature often includes prolonged medicinal iron ingestion as a cause of illness by iron overload ${ }^{(1,7-10)}$. A review of these cases would therefore be an excellent opportunity to clarify how this hematologic condition behaves.

Iron overload due to prolonged medicinal iron ingestion is an extremely rare occurrence. After an exhaustive search we found 12 published cases whose data are presented in Table 1. Ten were female with ages ranging from 10 to 77 years, the treatment time was 5 to 49 years and the total amount of ingested medicine (determined in eight patients) ranged from 500 to $26,300 \mathrm{~g}$.

Table 1 - Cases of iron overload due to ingesting medicinal iron

\begin{tabular}{|c|c|c|c|c|c|c|c|c|c|c|}
\hline $\mathbf{N}^{\circ}$ & Age & Gender & $\begin{array}{l}\text { Duration of iron } \\
\text { ingestion (years) }\end{array}$ & Liver & Diabetes & Heart & $\begin{array}{l}\text { Skin } \\
\text { Color }\end{array}$ & Serum iron & Others & Ref \\
\hline 2 & 75 & M & 12 & Cirrhosis & $\mathrm{N}$ & + & + & 209 & Hereditary spherocytosis & (12) \\
\hline 3 & 75 & $\mathrm{~F}$ & 47 & Cirrhosis & + & + & + & $\begin{array}{l}200 \\
\text { Saturation rate }=100 \%\end{array}$ & $\begin{array}{l}\text { Death } \\
\text { hepatic coma } \\
\text { hemochromatosis (A) }\end{array}$ & (13) \\
\hline 4 & & $\mathrm{~F}$ & 13 & Cirrhosis & $\mathrm{N}$ & + & + & $\mathrm{N}$ & $\begin{array}{l}\text { Hereditary non-spherocytic } \\
\text { hemolytic anemia } \\
\text { portal hypertension } \\
\text { hemochromatosis (A) }\end{array}$ & (14) \\
\hline 5 & 60 & F & 27 & + & $\mathrm{N}$ & $\mathrm{N}$ & + & $\begin{array}{l}246 \\
\text { Saturation rate }=100 \%\end{array}$ & Hemochromatosis (B) & (15) \\
\hline 7 & 70 & F & 10 & + & + & + & + & 282 & Hemochromatosis (A) & (17) \\
\hline 8 & 55 & F & 19 & $\mathrm{~N}$ & $\mathrm{~N}$ & $\mathrm{~N}$ & & 127 & $\begin{array}{l}\text { Siderosis was not discarded } \\
\text { took } 4644 \mathrm{~g} \text { iron }\end{array}$ & (18) \\
\hline 9 & 77 & $\mathrm{~F}$ & 25 & Cirrhosis & $\mathrm{N}$ & $\mathrm{N}$ & + & $\begin{array}{l}225 \\
\text { Saturation rate }=90 \%\end{array}$ & $\begin{array}{l}144 \text { phlebotomies with accentuated } \\
\text { histological improvement }\end{array}$ & (19) \\
\hline 10 & 58 & M & 26 & Cirrhosis & + & + & + & 268 & Depression hemochromatosis (B) & (20) \\
\hline 11 & 63 & $\mathrm{~F}$ & 20 & Deposit & $\mathrm{N}$ & & & $\begin{array}{l}227 \\
\text { Saturation rate }=92 \%\end{array}$ & Treated with intramuscular iron & (21) \\
\hline 12 & 10 & $\mathrm{~F}$ & 5 & hemosiderosis & $\mathrm{N}$ & $\mathrm{N}$ & $\mathrm{N}$ & 215 & $\begin{array}{l}\text { Without mutations of the HFE gene } \\
\text { only child case } \\
\text { recovered }\end{array}$ & (22) \\
\hline
\end{tabular}


Some important information was found in respect to these rare diseases:

- a great predominance of women as was expected, as it would not take such a long time for the disease to manifest in men with such large intakes of iron;

- Case 3 took 26,320 grams of iron and presented advanced liver cirrhosis, portal hypertension, anemia, dark skin, heart murmurs and died in a hepatic coma with ammonia poisoning; two other patients also had portal hypertension, and died after the rupture of esophageal varices;

- other clinical manifestations were: diabetes ( 5 cases), heart disease (6 cases), and dark skin (9 cases);

- Case 11 was the only case in which iron administration was intramuscular;

- Case 12 was the only registered occurrence of a child and, along with the Cases 9 and 11, there was an improvement in the disease with therapy;

- with the exception of the child, all cases were seen prior to the discovery of chromosomal mutations;

- based on data of the autopsy or biopsy, the authors found that six cases were instances of hemochromatosis in women.

Discussing this subject, Beutler ${ }^{(7)}$, in the 8th edition of Williams Hematology, states: The homeostatic mechanisms of the body are such that the improper administration of oral iron is very unlikely to produce clinically significant iron overload. Of the few cases described all except one (a child without tissue damage) were documented before the HFE gene clone appeared, leaving open the distinct possibility that patients were simply cases of hemochromatosis whose disease was accelerated by the excessive intake of iron.

\section{Amount of iron ingested by a Brazilian citizen per day}

It is very difficult to determine the amount of iron that is ingested every day by the Brazil population in the current system of universal food fortification. In addition to the amount in a normal diet (which is about $14 \mathrm{mg}$ per day), Brazilians ingest iron from fortified foods and, occasionally, from products enriched for commercial purposes. Recently the results of an inspection carried out in ten mills of Fortaleza were reported by the Health Department of the State of Ceará in the northeast of Brazil. The results show that there is a wide variation in the iron content of the wheat flour produced by these mills. The iron content of samples ranged from $4.23 \mathrm{mg}$ to $6.65 \mathrm{mg}$ per 100 grams and thus the levels were approved by the local authorities as they reached the minimum value specified by law. Hence, the daily amount of iron that is ingested by a Brazilian citizen will also depend on the amount of metal in each batch of flour.

The mandatory fortification program in Brazil has been in force for 3072 days now. To get an idea of how much iron a Brazilian citizen ingested during this period we used a simple simulation: one kilogram of wheat flour produces 18 bread rolls with $3.3 \mathrm{mg}$ of iron in each. If a person eats three rolls per day (that is $10 \mathrm{mg}$ of iron per day) over 3072 days he has ingested a total of $30,720 \mathrm{mg}$ of iron in addition to the amount in the normal diet. In this way three situations arise:
- patients with iron deficiency anemia may benefit by controlling the lack of metal;

- the normal person, who has a good control system of ingested iron, absorbs only what he needs; however, he took a total of $30,720 \mathrm{mg}$ metal, which is the equivalent of 762 40-mg iron tablets. In this respect the book, Guidelines on food fortification with micronutrients ${ }^{(23)}$ of the World Health Organization and the Food and Agriculture Organization of the United Nations (WHO/FAO) already foresaw: when a population is exposed to increased nutrients in food it is to be expected that many will benefit and others will not.

- on the other hand the patient with hemochromatosis, who has an increased rate of iron absorption ${ }^{(1)}$, may retain high deposits of iron, a burden that will be added to existing iron in the tissues.

Although this amount of iron to far different to that observed in the cases described above with 'medical iron intake', it is sure that some cases of hemochromatosis in the Brazilian population will be speeded up. An aggravating circumstance is that it has not been defined when the obligatory fortification of food according to Resolution 344 of ANVISA should be discontinued.

\section{Universal fortification of foods with iron: a 'low-cost practical solution'}

In truth, Resolution 344 of ANVISA is a practical measure, but it is not cost effective for the patient, who pays all the costs of treatment. Thus, a 40-mg tablet of ferrous sulfate costs about 33 cents (US \$0.16) in pharmacies; over one month, a patient with iron deficiency, taking one tablet per day, will spend $\mathrm{R} \$ 9.90$ (US $\$ 4,76$ ). With fortified diets, taking into account that one kilogram of bread contains $42 \mathrm{mg}$ of iron with a cost of $\mathrm{R} \$ 8.00$ (US \$3.84) in supermarkets, the patient would spend $\mathrm{R} \$ 240.00$ in one month for the same treatment. Of course, in this latter situation, the nutritional value of bread must be remembered.

In Guidelines on food fortification with micronutrients ${ }^{(23)}$, the authors affirm: "Fortified foods often fail to reach the poorest segments of the general population, which have the greatest risk of micronutrient deficiencies. This is because these groups always have restricted access to fortified foods due to their low income and the underdeveloped distribution channel". Hence, we question whether, with universal fortification, we are not favoring only the more privileged classes?

When the cost of a treatment is calculated, expenses related to complications that arise with the therapy must also be considered. Universal fortification may result in an increase in patients with iron overload (hemochromatosis, transfusional hemosiderosis, etc.) which will certainly increase the cost to the healthcare system, with the need of frequent phlebotomies, high-cost treatments with iron chelators, treatment for diabetics and, exceptionally, transplantation for liver cancer.

\section{The World Health Organization and food fortification}

Food fortification has been considered by some authors to be the best strategy to increase iron intake of a population, especially for children and pregnant women ${ }^{(24,25)}$. The World Health Organization recognizes four types of fortification: universal or mass, open market (commercial), targeted (for high-risk groups), 
and household and community fortification. The guidelines of these fortifications are described in detail in the book Guidelines on food fortification with micronutrients ${ }^{(23)}$. This is a work of great scientific content published by the following editors:

- Lindsay Allen, Director of the United States Department of Agriculture (USDA), agricultural research service at the University of California, USA;

- Bruno de Benoist, Coordinator of the Micronutrient Unit, WHO, Geneva, Switzerland;

- Omar Dary, Food Fortification expert, Academy for Educational Development, Washington, USA;

- Richard Hurrel, Director of the Human Nutrition Laboratory, Swiss Federal Institute of technology, Zurich, Switzerland.

Six other distinguished personalities from the fields of economics, social sciences, nutrition, and food and nutritional sciences also collaborated in this magnificent work. It is strange that no hematologist was included in a work by the World Health Organization with so many renowned researchers; a hematologist, of course, would increase the understanding about the effects of offering iron to needy populations.

\section{Universal iron fortification of foods}

Guidelines on food fortification with micronutrients ${ }^{(23)}$, defines fortification as "the practice of deliberately increasing the content of an essential micronutrient, for example, vitamins and minerals (including trace elements) in food, to improve the nutritional quality of the food supply to produce a benefit to public health with a minimal risk to health". Universal iron fortification of foods certainly results in some beneficial effects in the needy population, in particular in children with nutritional deficiencies. However, should it be allowed to accelerate the evolution of cases of hemochromatosis and other illnesses involving iron overload? Numerous works have been published on this theme.

The fortification of wheat flour with iron has been used in Canada, Great Britain and United States since 1940 with control of iron deficiency being provided in these countries. In recent years there has been growing interest of fortification programs in developing nations ${ }^{(26)}$.

However, the fortification of foods with iron was suspended in Sweden in 1994. This was considered one of the largest fortifications in the world with the addition of $4.1 \mathrm{mg}$ of iron per 100 grams of flour. At that time, Olsson et al. ${ }^{(27)}$ studied 16 patients with hemochromatosis, during and after a period stopping fortification and found that there was a decrease of $0.65 \mathrm{mg}$ iron absorbed per day and that the range of phlebotomies increased by 10 days. On applying these data to Brazil, a patient with hemochromatosis absorbed a total of $1996.8 \mathrm{mg}$ of iron in 3072 days.

Denmark also suspended the fortification of wheat flour with iron in 1987. Millman (apud Lynch ${ }^{(26)}$ ) reports that this fortification had no effect on the prevalence of iron deficiency in men and in over 40-year-old women in the pre- and post-menopausal periods.

Lynch $^{(26)}$, in a detailed work on the risk of iron fortification and nutritional anemia arrived at the following conclusion: "The only very well-documented risk of universal fortification is an increase in the rate of accumulation of iron in individuals with the HFE phenotypic of hemochromatosis who may require more frequent phlebotomies. An increased absorption of iron can also be expected in anemic patients with iron overload".

Adamson, in the 6th edition of the book Harrison ${ }^{(28)}$, says that there has been a decline in interest for the supplementation of iron in bread and cereals due to the prevalence of the hemochromatosis gene, which would result in a high risk of overload in these patients

\section{Market-driven Fortification in Brazil}

Guidelines on food fortification with nutrients ${ }^{(23)}$ recognizes that market-driven fortification can play a positive role in public health to needy populations by offering some products that they need. The choice is voluntary and is characterized by being able to add a higher quantity of a particular nutrient that cannot be done in universal fortification because of technical and safety issues. This type of fortification is more widespread in industrialized countries. Thus, by giving the population, in particular children, a wide range of products enriched with iron, a remarkable contribution will be given to the Brazilian Government to solve the problem of iron deficiency.

\section{The hemochromatosis patient}

The patient with hemochromatosis is the one who is most handicapped by Resolution 344 of ANVISA, as he is practically forced to ingest a larger amount of iron. Hemochromatosis was first described by Trousseau in 1865. It was considered a rare disease, an inborn error of the metabolism. With the discovery of chromosomal mutations at the end of the last century this was proven different; there is a high frequency of the disease not only in Nordic countries but in other regions of the world. In Brazil it is frequent, judging by numerous papers presented in National Congresses ${ }^{(2-4)}$.

The disease is characterized by an inappropriate increase in intestinal absorption of iron and its accumulation in organs and tissues including the liver, spleen, heart, pancreas, endocrine glands, skin and joints. Clinical manifestations generally appear in the third and fourth decade of life, accompanied by general symptoms of fatigue, depression, joint pain, abdominal pain, hair loss etc. As a result of the idea that it is a rare illness, many patients in the United States consult several different physicians before the disease is diagnosed ${ }^{(29)}$.

It is of fundamental importance that the diagnosis is made early because phlebotomy therapy regresses clinical manifestations such as cirrhosis and increases the survival rate of these patients to close to that of normal people.

Due to the frequency of the disease and the need for an early diagnosis, hemochromatosis should be considered a public health problem $^{(30)}$. Hemochromatosis should have the same status as high blood pressure, diabetes, obesity and metabolic syndrome and should have research programs to better understand the disease.

\section{Conclusion}

We are not against iron fortification of foods in its different modes: targeted or market-driven. This would mean to ignore the numerous studies carried out by the group from Sao Paulo in this important area of food fortification, which aims to combat iron deficiency. However, we are against mass food fortification, because we believe that one cannot correct one problem (iron 
deficiency) and exacerbate another condition (acceleration of cases of hemochromatosis) which is as severe as the first.

With the objective of collaborating with the health authorities we are suggesting that Resolution 344 of ANVISA should be reconsidered to find a solution that is beneficial to all segments of the population in Brazil. We suggest that a proportion of industrialized wheat flours in Brazil should be sold without the addition of iron. It would be what we would call 'semi-universal' fortification. For the Brazilian industry, which has helped us so much in this process of food fortification, this would be an excellent opportunity to diversify their products!

To conclude we should remember:

- every diabetic has the right to have food without glucose;

- every patient with coeliac disease has the right to gluten-free food;

- every patient with hypertension have the right to food without salt;

Why is the patient with iron overload not entitled to food without iron?

\section{HUMAN RIGHTS MUST BE FOR EVERYONE!}

\section{References}

1. Cançado RD, Chiattone CS. Visão atual da hemocromatose hereditária. Rev Bras Hematol Hemoter. 2010;32(6):469-75.

2. Leão GD, Oliveira TM, Freire JM, Fernandes AL, Vasconcelos RC, Gil EA, et al. Hemocromatose hereditária: avaliação da mutação H63D do gene HFE em um grupo de indivíduos com hiperferritinemia persistente. Rev Bras Hemat Hemoter. 2009; 31(Supl 5):10. [abstract 0013]. Paper presented at: $8^{\text {th }}$ Encontro Anual da Associação Ítalo-Brasileira de Hematologia.

3. Oliveira TM, Leão GD, Freire JM, Fernandes AL, Vasconcelos RC, Gil EA et al. Frequência das mutações C282Y, H63D e S65C do gene HFE em pacientes com suspeita de hemocromatose hereditária. Rev Bras Hemat Hemoter. 2009;31( Supl 5):10. [abstract 0012]. Paper presented at: $8^{\text {th }}$ Encontro Anual da Associação Ítalo-Brasileira de Hematologia.

4. Santos PC, Pereira AC, Cançado RD, Teixeira AC, Sobreira TJ, Hirata $\mathrm{RD}$, et al. Hereditary hemochromatosis: HFE gene sequencing in Brazilian patients with primary iron overload. Rev Bras Hemat Hemoter. 2009; 31(Supl 5):11. [abstract 0014]. Paper presented at: $8^{\text {th }}$ Encontro Anual da Associação Ítalo-Brasileira de Hematologia.

5. Brasil. Ministério da Saúde. Agência Nacional de Vigilância Sanitária. Resolução RCD n. 344, de 13 de dezembro de 2002. Aprova o regulamento técnico para a fortificação das farinhas de trigo e milho com ferro e ácido fólico [Internet]. Brasília: Ministério da Saúde; 2002. [cited 2011 Apr 11]. Available from: http://www.anvisa.gov.br/legis/ resol/2002/344_02rdc.htm

6. Martins JM. Considerations on the food fortifications policy in Brazil. Rev Bras Hematol Hemoter [Internet]. 2011 [cited 2012 Oct 21];33(2): 158-63. Available from: http://www.scielo.br/pdf/rbhh/v33n2/v33n2a17.pdf

7. Beutler E. Disorders of iron metabolism. In: Kaushansky K, Beutler E, Seligsohn U, Lichtman MA, Kipps TJ, Prchal, JT, editors. Williams Hematology. $8^{\text {th }}$ ed. New York: McGraw-Hill; 2010. p.592-610.

8. Beutler E, Fairbanks VF, Fahey JL. Clinical disorders of iron metabolism. New York: Grune \& Stratton; 1963. 227 p.

9. Alberto FL. Sobrecarga de ferro: hemocromatose hereditária e adquirida.
In: Zago MA, Falcão RP, Pasquini, R. Hematologia. Fundamentos e prática. São Paulo: Atheneu; 2001. p. 231-7.

10. McLaren, GD. Hereditary hemochromatosis and other iron-overload disorders. In: Mazza JJ. Manual of clinical hematology. $3^{\text {rd }}$ ed. Philadelphia: Lippincott Williams \& Wilkins; 2002. p. 119.

11. WEEKLY clinicopathological exercises, exogenous hemochromatosis due to iron ingestion. N Eng J Med. 1952;247(25):992-5.

12. Wallerstein RO, Robbins SL. Hemochromatosis after prolonged iron therapy in a patient with chronic hemolytic anemia. Am J Med. 1953;14(2):256-60.

13. Case records of the Massachusetts General Hospital. Case 44131. N Engl J Med. 1958;258(13):652-61.

14. Pletcher WD, Brody GL, Meyers MC. Hemochromatosis following prolonged iron therapy in a patient with hereditary nonspherocytic hemolytic anemia. Am J Med Sci. 1963;246:27-34.

15. Turnberg LA. Excessive oral iron therapy causing haemochromatosis. $\mathrm{Br}$ Med J. 1965;1(5446):1360.

16. Castleman, B, McNeely, BU. Case records of the Massachusetts General Hospital. Case 56. N Engl J Med. 1965;273(27):1483-91. Comment in: N Engl J Med. 1966;274(14):803.

17. Johnson BF. Hemochromatosis resulting from prolonged iron therapy. $\mathrm{N}$ Engl J Med. 1968;278(20):1100-1.

18. Murphy KJ. 4,644 grammes of oral ferrous sulphate (over 19 years) without apparent damage. Report of case. Med J Aust. 1968;1(24):1051-2.

19. Wheby MS. Medicinal iron-induced hepatic cirrhosis: reversal by phlebotomy: studies on pathogenesis. Trans Am Clin Climatol Assoc. 1978;89:100-8.

20. Hennigar GR, Greene WB, Walker EM, de Saussure C. Hemochromatosis caused by excessive vitamin iron intake. Am J Pathol. 1979;96(2):611-24.

21. Saven A, Beutler E. Iron overload after prolonged intramuscular iron therapy. N Engl J Med. 1989;321(5):331-2.

22. Pearson HA, Ehrenkranz RA, Rinder HM, Riely CA. Hemosiderosis in a normal child secondary to oral iron medication. Pediatrics. 2000;105(2):429-31.

23. Allen L, Benoist B, Dary O, Hurrell R. Guidelines on food fortification with micronutrients [Internet]. Geneva: World Health Organization/Food and Agricultural Organization; 2006 [cited 2012 Dec 20]. Available from: http://www.who.int/nutrition/publications/guide_food_fortification_ micronutrients.pdf

24. Vellozo EP, Fisberg M. O impacto da fortificação de alimentos na prevenção da deficiência de ferro. Rev Bras Hematol Hemoter. 2010;32(Supl. 2):134-9.

25. Szarfarc SC. Políticas públicas para o controle da anemia ferropriva. Rev Bras Hematol Hemoter. 2010; 32(Supl 2);2-7.

26. Lynch SR. The impact of iron fortification on nutricional anaemia. Best Pract Res Clin Haematol. 2005;18(2):333-46.

27. Olsson KS, Väisänen M, Konar J, Bruce A. The effect of withdraw of food fortification in Sweden as studied with phlebotomy in subjects with genetichemochromatosis. Eur J Clin Nutr. 1997;51(11):782-6.

28. Adamson JW. Iron defficiency and other hypoproliferative anemias. In: Kasper DL, Fauci AS, Longo DL, Braunwald E, Hause SL, Jameson JL, editors. Harrison's Principles of Internal Medicine. $16^{\text {th }}$ ed. New York: McGraw-Hill; 2005. p. 588-92.

29. Garrison C. The hemochromatosis cookbook: recipes and meals for reducing the absorption of iron in your diet. Napperville: Sourcebook; 2008. $299 \mathrm{p}$

30. Wetterhall SF, Cogswell ME, Kowdley KV. Public health surveillance for hereditary hemochromatosis. Ann Intern Med. 1998;129(11):980-6. 